\title{
Changes in physiological indicators associated with salt tolerance in two contrasting cashew rootstocks
}

\author{
Sérgio L. Ferreira-Silva ${ }^{1}$, Joaquim A.G. Silveira ${ }^{1 *}$, Eduardo L. Voigt ${ }^{1}$, Lucilene S.P. Soares ${ }^{1}$ and \\ Ricardo A. Viégas ${ }^{2}$
}

${ }^{1}$ Departamento de Bioquímica e Biologia Molecular, Universidade Federal do Ceará, CP 6020, 60451-970 Fortaleza, CE, Brasil; ${ }^{2}$ Departamento de Engenharia Florestal, Universidade Federal de Campina Grande, Campus II, CP 64, 58700-970 Patos, PB, Brasil. *Corresponding author: silveira@ufc.br; Tel./Fax: +55 8533669821

Received: 31 January 2008; Returned for revision: 24 March 2008; Accepted: 05 April 2008

In order to identify salt tolerance indicators, several physiological variables were evaluated in two contrasting cashew (Anacardium occidentale L.) rootstocks in response to salt stress. The tolerant CCP 09 genotype showed better growth performance after two weeks under a large range of $\mathrm{NaCl}$ salinity $(50,100,150$ and $200 \mathrm{mM})$. The $\mathrm{NaCl}$ treatments induced a significant drop in transpiration as a consequence of an increased stomatal resistance in both genotypes. No significant differences in $\mathrm{Na}^{+}, \mathrm{Cl}^{-}$, and $\mathrm{K}^{+}$concentrations were found in both roots and leaves regardless of rootstocks. The tolerant genotype exhibited lower relative water content and less negative leaf osmotic potential as compared with the sensitive genotype and, therefore, these variables could not be related to salt tolerance. Salt stress caused more significant changes in protein and amino acid concentrations in roots than in leaves. Among the physiological indicators, leaf membrane damage was closely associated with the differences in salt tolerance between the two cashew genotypes. Furthermore, under $\mathrm{NaCl}$ salinity the tolerant rootstock showed greater ability to accumulate compatible organic solutes (amino acids, proline and soluble sugars) in leaves in addition to maintaining the soluble sugar concentration in roots as compared with the sensitive rootstock.

Key words: Anacardium occidentale, organic solutes, salt stress, salt tolerance, sodium and chloride partitioning, sodium-to-potassium ratio

Mudanças em indicadores fisiológicos associados com a tolerância ao estresse salino em dois porta-enxertos
contrastantes de cajueiro: Com o objetivo de identificar marcadores fisiológicos de tolerância ao estresse salino, diversas
variáveis fisiológicas foram avaliadas em dois porta-enxertos de cajueiro (Anacardium occidentale L.) apresentando
contraste na tolerância à salinidade. O genótipo tolerante (CCP 09) apresentou melhor crescimento sob todas as
concentrações de $\mathrm{NaCl}(50,100,150$ e $200 \mathrm{mM}$ ), após duas semanas. O tratamento salino reduziu severamente a
transpiração, como conseqüência do aumento substancial da resistência estomática nos dois genótipos. Os dois porta-
enxertos não apresentaram diferenças significativas nas concentrações de $\mathrm{Na}^{+}, \mathrm{Cl}^{-}$e $\mathrm{K}^{+}$nos tecidos de raízes e folhas. O
genótipo tolerante, em comparação com o sensível, apresentou menor conteúdo relativo de água e maior (menos negativo)
potencial osmótico foliar, de maneira que essas variáveis não devem estar associadas com a tolerância ao sal na espécie em
questão. O estresse salino induziu mudanças significantemente maiores nas concentrações de proteína e aminoácidos em
raízes do que em folhas, sugerindo que a raiz foi o órgão mais sensível ao sal. Entre os indicadores fisiológicos avaliados,
o dano de membrana foi o que mais bem se associou com a diferença de tolerância ao estresse salino entre os dois
genótipos. Em adição, o porta-enxerto tolerante apresentou maior acúmulo de solutos orgânicos (aminoácidos, prolina e
açúcares solúveis) em folhas, além de manter, em maior extensão, a concentração de açúcares solúveis em raízes comparado
ao sensível, em resposta ao NaCl. Palavras-chave: Anacardium occidentale, estresse salino, partição de $\mathrm{Na}^{+}$e $\mathrm{Cl}^{-}$, relação $\mathrm{Na}^{+} / \mathrm{K}^{+}$, solutos orgânicos, tolerância ao sal 


\section{INTRODUCTION}

High soil salinity accounts for considerable yield losses of a wide variety of crops all over the world. This problem is more severe in semi-arid regions (Munns, 2002), including the Northeast of Brazil, where it is one of the major limiting factors to crop productivity. This problem can be prevented or mitigated by soil and water management, and crop productivity under salt stress could be improved using tolerant genotypes (Ashraf and Ahmad, 2000).

Salt stress could inhibit plant growth and reduce plant productivity by water deficit, ionic toxicity and nutritional imbalance (Munns, 2002). Water deficit is the primary effect of salt stress due to lowered water potential of the soil solution and restricting root water uptake. In some glycophytes, the ability to undergo osmotic adjustment is related to the accumulation of organic solutes such as $\mathrm{N}$-compounds, especially proline and glycine-betaine, soluble sugars and salt stress proteins (Ashraf and Harris, 2004). Thus, the accumulation of these compounds improves water uptake under salt stress and possibly protects the cell structure against molecular disturbances, resulting in plant acclimation (Munns et al., 2006).

In addition to the osmotic effects of soil salinity, $\mathrm{Na}^{+}$ and $\mathrm{Cl}^{-}$uptake and accumulation in plant tissues result in ionic toxicity due to intense changes in the $\mathrm{Na}^{+} / \mathrm{K}^{+}, \mathrm{Na}^{+}$/ $\mathrm{Ca}^{+2}$ and $\mathrm{Cl}^{-} / \mathrm{NO}_{3}^{-}$ratios in the cell compartments (Amtmann and Maathuis, 1999; Blumwald et al., 2000). Competitive interactions among toxic ions $\left(\mathrm{Na}^{+}\right.$and $\left.\mathrm{Cl}^{-}\right)$ and nutrients in the soil could induce nutrient deficiencies (Grattan and Grieve, 1999). Moreover, the alteration of ion interactions in the cell compartments could damage basic biochemical and physiological processes, such as photosynthesis, respiration, protein synthesis and the maintenance of turgor pressure and charge balance (Amtmann and Maathuis, 1999). In this way, the ability to maintain continuous growth and exclude toxic ions from the leaves has been associated with the resistance of many crops against salt stress (Munns, 2002). The uptake and partitioning of $\mathrm{Na}^{+}$and $\mathrm{Cl}^{--}$throughout the whole plant are, therefore, important traits to discriminate among salt-tolerant and saltsensitive genotypes (Ashraf and Ahmad, 2000; Ashraf and Harris, 2004).
The elucidation of physiological mechanisms related to salt tolerance in crops is crucial to reach more effective resolutions of practical problems caused by salinity in cultivated lands. One possibility to overcome productivity losses caused by salinity in high-yielding genotypes would be the grafting of these varieties onto rootstocks capable of allowing salt tolerance in the shoot. This strategy could also provide plants combining good shoot characters with good root traits (Zijlstra et al., 1994). Nevertheless, salt tolerance is a polygenic trait involving a complex network of molecular, biochemical, and physiological processes which strongly interact with the environmental factors (Flowers, 2004; Munns et al., 2006). Thus, the identification and characterization of physiological variables as efficient markers to evaluate salt tolerance in different crop species are still far from being achieved (Ashraf and Harris, 2004).

The crop species utilized in this study is cashew (Anacardium occidentale L.), an important fruit (nut) crop well adapted to grow under semi-arid conditions in the Northeast of Brazil, where it is often subjected to drought and salinity (Viégas et al., 2001). This species presents mild resistance to salinity, surviving under high external $\mathrm{NaCl}$ concentrations $(200 \mathrm{mM})$ during several weeks (Ferreira-Silva, 2004). Studies on the comparative physiology involving the responses of cashew rootstocks and of other fruits exposed to salt stress are scarce (Matos et al., 2003). In a previous study, FerreiraSilva (2004) studied the salt tolerance of ten cashew genotypes after seedling establishment and characterized the CCP 06 and CCP 09 genotypes as sensitive and tolerant to salt stress, respectively. These genotypes showed contrasting responses in terms of plant growth and salt-induced leaf injuries. In this study, a comparative analysis using these cashew genotypes was carried out under a range of $\mathrm{NaCl}$ levels in order to characterize their responses to salt stress in terms of growth, ionic homeostasis, organic solute accumulation, water relations and membrane stability. Furthermore, some physiological variables directly related to those processes were evaluated as salt tolerance indicators.

\section{MATERIAL AND METHODS}

Plant material and growth conditions: Nuts from two cashew (Anacardium occidentale L.) genotypes (CCP 06 
and CCP 09, respectively sensitive and tolerant to salt stress) were kindly provided by the Empresa Brasileira de Pesquisa Agropecuária (EMBRAPA), Brazil. The nuts were sown in $1 \mathrm{~L}$ pots filled with sand and irrigated daily with distilled water up to $70 \%$ of substrate field capacity. After the whole seedling establishment $(30 \mathrm{~d})$, a set of homogeneous plants (at the eight-leaf stage) was selected and irrigated every $2 \mathrm{~d}$ with twice-diluted Hoagland's nutrient solution (Hoagland \& Arnon, 1950) and supplied with $0,50,100,150$ and $200 \mathrm{mM} \mathrm{NaCl}$ for two weeks. The final concentrations were reached by a gradual increment of 50 $\mathrm{mM} \mathrm{NaCl}$ every day. The experiment was carried out in a greenhouse under natural conditions with the following mean values: $12 \mathrm{~h}$ photoperiod, approximately $700 \mu \mathrm{mol} \mathrm{m}^{-2}$ $\mathrm{s}^{-1}$ of maximum photosynthetically active radiation (PAR), $55 \%$ relative humidity, and temperature ranging from $29^{\circ} \mathrm{C}$ (day) to $24^{\circ} \mathrm{C}$ (night). At harvest, plants were divided into leaves, stem and roots. Plant parts were then frozen at $-80^{\circ} \mathrm{C}$ and lyophilized.

Transpiration rate and stomatal resistance: Transpiration and stomatal resistance measurements were done two weeks after initiating the salt treatments using a steady state porometer (model LI-1600, LiCor, Lincoln, USA). All measurements, made between 0930 and $1000 \mathrm{~h}$ when environmental fluctuations were relatively low, were conducted using one mature leaf from the middle of the shoot of each experimental plot (see below).

Osmotic Potential: For osmolality measurements $0.5 \mathrm{~g}$ leaf material (fresh mass) was quickly macerated in a mortar with liquid $\mathrm{N}_{2}$. The extract was filtered using a miracloth membrane and the filtrate centrifuged at $10.000 \mathrm{x} g$ during 10 $\min$ at $4^{\circ} \mathrm{C}$. Subsequently, supernatants $(10 \mu \mathrm{L})$ were used to determine the osmolality using a vapor pressure osmometer (Vapro 5520, Wescor, USA) according to the manufacturer's instructions. Osmolality $\left(\mathrm{mmol} \mathrm{kg}{ }^{-1}\right)$ was converted to osmotic potential $\left(\Psi_{s}\right)$ using the relation: $1 \mathrm{mmol} \mathrm{kg}^{-1}=2.408$ x $10^{-3} \mathrm{MPa}$ (Santa-Cruz et al., 2002).

Inorganic and organic solutes: The plant material was finely ground and digested with a nitric acid-perchloric acid mixture. Ions $\mathrm{Na}^{+}$and $\mathrm{K}^{+}$were determined by flame photometry and $\mathrm{Cl}^{-}$by titration with $\mathrm{AgNO}_{3}$ (Viégas et al., 2001). After extraction with $80 \%$ (v/v) ethanol, soluble sugars (Dubois et al., 1956), total free amino acids (Yemm and Cocking, 1955), and proline (Bates et al., 1973) were determined. Soluble protein was extracted with $50 \mathrm{mM}$ Tris-HCl buffer $\mathrm{pH} 7.6$ and determined according to Bradford (1976) using BSA as a standard.

Relative water content $(R W C)$ and membrane damage: The leaf RWC and membrane damages were determined as described elsewhere (Cavalcanti et al., 2004). Thirty leaf discs $(1.0 \mathrm{~cm}$ in diameter) were sampled and immediately weighed (fresh mass, FM), immersed in distilled water at $25^{\circ} \mathrm{C}$ for $7 \mathrm{~h}$ under a photon flux density of $40 \mu \mathrm{mol} \mathrm{m}^{-2} \mathrm{~s}^{-1}$. The leaf discs were then blotted on filter paper and the turgid mass (TM) was determined. The discs were dried at $80^{\circ} \mathrm{C}$ for $48 \mathrm{~h}$ and the dry mass (DM) was measured. The RWC was calculated using the equation $\mathrm{RWC}=[(\mathrm{FM}-\mathrm{DM}) /(\mathrm{TM}-\mathrm{DM})] \mathrm{x} 100$.

The leaf membrane damage (MD) was estimated on the basis of $\mathrm{K}^{+}$leakage. Twenty leaf discs $(1.0 \mathrm{~cm}$ in diameter) were incubated in deionized water at $25^{\circ} \mathrm{C}$ for $24 \mathrm{~h}\left(\mathrm{~L}_{1}\right)$ and the $\mathrm{K}^{+}$concentration in the leach was determined by flame photometry. Then, the discs were boiled for $1 \mathrm{~h}$ and the $\mathrm{K}^{+}$ concentration was measured again $\left(\mathrm{L}_{2}\right)$. The percentage of membrane damage was estimated according to the equation $\operatorname{MD}(\%)=\left(\mathrm{L}_{1} / \mathrm{L}_{2}\right) \times 100$. The MD was also measured in terms of electrical conductivity and the obtained results were similar to that verified by $\mathrm{K}^{+}$leakage. As the $\mathrm{K}^{+}$leakage is more adequate to indicate membrane disturbances than total electrolyte leakage, the relative $\mathrm{K}^{+}$leakage was adopted as an MD indicator.

Experimental design and data analysis: The experiment was carried out according to a completely randomized design in a $2 \times 5$ factorial (two genotypes and five salt concentrations). The data were obtained in four independent replications per treatment of single plant experimental plots. The experiment was repeated twice showing similar trends. The data were subjected to an analysis of variance and the means were compared by Tukey's test at the 0.05 probability level.

\section{RESULTS}

Plant growth and ionic homeostasis: After two weeks of $\mathrm{NaCl}$ treatment, the cashew genotypes we evaluated showed differential responses in plant growth and visual symptoms of leaf injury. The tolerant CCP 09 genotype 
showed greater dry mass accumulation in both roots and shoots than the sensitive CCP 06. For instance, at $200 \mathrm{mM}$ $\mathrm{NaCl}$ shoot dry mass was reduced by $42 \%$ and $35 \%$, respectively in sensitive and tolerant genotypes, in relation to the untreated controls. The shoot-to-root ratio was gradually elevated in the tolerant genotype as the $\mathrm{NaCl}$ level increased, whilst such ratio remained almost unchanged in the sensitive one (Table 1). Additionally, the old leaves of the salt-treated plants showed variant visual symptoms of salt toxicity, which were characterized as drying spots in the sensitive CCP 06 and as chlorotic regions (yellowing) in the tolerant CCP 09 (data not shown).

The CCP 06 and CCP 09 plants had similar $\mathrm{Na}^{+}$and $\mathrm{Cl}^{-}$ concentrations in roots and shoots under all salt levels, as well as comparable patterns of ion partitioning (Table 2). The $\mathrm{Na}^{+}$concentration in both genotypes nearly doubled in roots relative to leaves, regardless of the $\mathrm{NaCl}$ treatments. In contrast, the $\mathrm{Cl}^{-}$concentration of the two genotypes was similar in roots and leaves, but leaf $\mathrm{Cl}^{-}$ was almost twice that verified for $\mathrm{Na}^{+}$at all salt treatments. Salt additions similarly affected $\mathrm{K}^{+}$ concentrations in both roots and leaves in either genotype (Table 2 ). In roots, $\mathrm{K}^{+}$concentration gradually decreased with increasing $\mathrm{NaCl}$ dose, and was half at 200 $\mathrm{mM} \mathrm{NaCl}$ as compared with control plants. In contrast, $\mathrm{K}^{+}$ concentration increased in leaves of plants treated with $100 \mathrm{mM} \mathrm{NaCl}$ and above. As a consequence, the $\mathrm{Na}^{+} / \mathrm{K}^{+}$ ratio was markedly increased in salt-treated plants, especially in roots. The $\mathrm{Na}^{+} / \mathrm{K}^{+}$ratio was increased by about 8- and 3.5-fold in roots and leaves, respectively, as compared with controls (Table 3 ).

Water relations and membrane damage: Salt stress similarly increased stomatal resistance $\left(r_{\mathrm{s}}\right)$ and restricted transpiration $(E)$ in both cashew genotypes (Table 1). At the greatest $\mathrm{NaCl}$ salinity $(200 \mathrm{mM}), r_{\mathrm{s}}$ increased by approximately 5.5 -fold and $E$ decreased by $85 \%$ in relation to control plants of both genotypes. The salt treatments slightly affected the leaf water status in the CCP 06 and CCP 09 plants as indicated by the RWC (Table 3). Concentrations of $\mathrm{NaCl}$ at 150 or $200 \mathrm{mM}$ did decrease RWC but only in the tolerant genotype. It is noteworthy that the salt-induced changes in leaf osmotic potential $\left(\Psi_{\mathrm{s}}\right)$ were more evident than the changes in RWC between the genotypes tested. Overall, the salt-treated plants of the tolerant genotype presented higher leaf $\Psi_{\mathrm{s}}$ values than the sensitive one, especially at 150 and $200 \mathrm{mM} \mathrm{NaCl}$ (Table 3).

The leaf membrane damage (MD), expressed as relative percentage of $\mathrm{K}^{+}$leakage, was significantly increased in salt-treated plants of both genotypes. Interestingly, the tolerant genotype showed lower MD values in all $\mathrm{NaCl}$ treatments, as compared with the sensitive one (Table 3 ). This physiological variable was strictly related to the differential responses of the CCP 06 and CCP 09 genotypes to $\mathrm{NaCl}$ salinity in terms of plant growth (Table 1).

Free amino acid and soluble sugar accumulation: The soluble protein concentration remained unchanged in leaves but it was halved in roots of both salt-treated

Table 1. Shoot and root dry mass, shoot/root ratio, transpiration $(E)$ and stomatal resistance $\left(r_{\mathrm{s}}\right)$ of two cashew rootstocks exposed to different $\mathrm{NaCl}$ levels during two weeks. Means followed by the same letter within the same column do not differ significantly by Tukey's test $(P>0.05) . n=4$.

\begin{tabular}{lcccccr}
\hline Genotypes & $\begin{array}{c}\mathrm{NaCl} \\
(\mathrm{mM})\end{array}$ & $\begin{array}{c}\text { Shoot } \\
\left(\mathrm{g} \mathrm{plant}^{-1}\right)\end{array}$ & $\begin{array}{c}\text { Root } \\
\left(\mathrm{g} \mathrm{plant}^{-1}\right)\end{array}$ & $\begin{array}{c}\text { Shoot/Root } \\
\text { ratio }\end{array}$ & $\begin{array}{c}E \\
\left(\mu \mathrm{g} \mathrm{H}_{2} \mathrm{O} \mathrm{cm}^{-2} \mathrm{~s}^{-1}\right)\end{array}$ & $\begin{array}{r}r_{\mathrm{s}} \\
\left(\mathrm{s} \mathrm{cm}^{-1}\right)\end{array}$ \\
\hline CCP 06 & 0 & $1.58 \mathrm{a}$ & $1.07 \mathrm{~b}$ & $1.48 \mathrm{~b}$ & $3.86 \mathrm{a}$ & $2.86 \mathrm{e}$ \\
& 50 & $1.26 \mathrm{~b}$ & $0.83 \mathrm{c}$ & $1.52 \mathrm{ab}$ & $0.98 \mathrm{~b}$ & $7.25 \mathrm{~d}$ \\
& 100 & $1.21 \mathrm{~b}$ & $0.78 \mathrm{c}$ & $1.55 \mathrm{ab}$ & $0.62 \mathrm{c}$ & $12.03 \mathrm{bc}$ \\
& 150 & $1.09 \mathrm{c}$ & $0.59 \mathrm{~d}$ & $1.45 \mathrm{~b}$ & $0.56 \mathrm{c}$ & $16.86 \mathrm{ab}$ \\
& 200 & $0.91 \mathrm{~d}$ & $0.63 \mathrm{~d}$ & $1.44 \mathrm{~b}$ & $0.56 \mathrm{c}$ & $19.73 \mathrm{a}$ \\
\hline CCP 09 & 0 & $1.75 \mathrm{a}$ & $1.27 \mathrm{a}$ & $1.38 \mathrm{~b}$ & $4.83 \mathrm{a}$ & $2.84 \mathrm{e}$ \\
& 50 & $1.54 \mathrm{a}$ & $1.11 \mathrm{ab}$ & $1.39 \mathrm{~b}$ & $0.89 \mathrm{~b}$ & $10.02 \mathrm{c}$ \\
& $1.46 \mathrm{a}$ & $0.93 \mathrm{~b}$ & $1.57 \mathrm{a}$ & $0.64 \mathrm{c}$ & $14.33 \mathrm{bc}$ \\
& 100 & $1.29 \mathrm{~b}$ & $0.81 \mathrm{c}$ & $1.59 \mathrm{a}$ & $0.64 \mathrm{c}$ & $16.86 \mathrm{ab}$ \\
& 150 & $1.13 \mathrm{c}$ & $0.72 \mathrm{c}$ & $1.57 \mathrm{a}$ & $0.54 \mathrm{c}$ & $18.13 \mathrm{a}$ \\
\hline
\end{tabular}

Braz. J. Plant Physiol., 20(1):51-59, 2008 
Table 2. Concentrations of $\mathrm{Na}^{+}, \mathrm{Cl}^{-}$, and $\mathrm{K}^{+}\left(\mathrm{mmol} \mathrm{kg}{ }^{-1} \mathrm{DM}\right)$ in root and leaves of two cashew rootstocks exposed to different $\mathrm{NaCl}$ levels for two weeks. Statistics as in Table 1.

\begin{tabular}{|c|c|c|c|c|c|c|c|}
\hline \multirow{2}{*}{ Genotypes } & \multirow{2}{*}{$\begin{array}{l}\mathrm{NaCl} \\
(\mathrm{mM})\end{array}$} & \multicolumn{2}{|c|}{$\mathrm{Na}^{+}$} & \multicolumn{2}{|c|}{$\mathrm{Cl}^{-}$} & \multicolumn{2}{|c|}{$\mathrm{K}^{+}$} \\
\hline & & Root & Leaf & Root & Leaf & Root & Leaf \\
\hline \multirow[t]{5}{*}{ ССР 06} & 0 & $260 \mathrm{c}$ & $98 \mathrm{~d}$ & $358 d$ & $248 \mathrm{c}$ & $286 a$ & $369 b$ \\
\hline & 50 & $886 b$ & $440 c$ & $767 \mathrm{c}$ & $771 b$ & $286 a$ & $382 b$ \\
\hline & 100 & $1078 \mathrm{a}$ & $510 \mathrm{~b}$ & $1119 b$ & $995 a$ & $189 \mathrm{~b}$ & $426 a$ \\
\hline & 150 & $1069 a$ & $631 \mathrm{a}$ & $1094 b$ & $1119 a$ & $184 b$ & $460 \mathrm{a}$ \\
\hline & 200 & $1182 \mathrm{a}$ & $606 a$ & $1360 \mathrm{a}$ & $1194 a$ & $143 c$ & $488 \mathrm{a}$ \\
\hline \multirow[t]{5}{*}{$\overline{\mathrm{CCP} 09}$} & 0 & $208 \mathrm{c}$ & $115 d$ & $299 d$ & $248 \mathrm{c}$ & $281 \mathrm{a}$ & $375 c$ \\
\hline & 50 & $773 b$ & $405 c$ & $731 \mathrm{c}$ & $895 b$ & $245 \mathrm{a}$ & $375 c$ \\
\hline & 100 & $1052 \mathrm{a}$ & $510 \mathrm{~b}$ & $1063 b$ & $1169 a$ & $235 \mathrm{a}$ & $413 a$ \\
\hline & 150 & $1034 a$ & $643 a$ & $1029 b$ & $1294 a$ & $163 b$ & $453 a$ \\
\hline & 200 & $1112 \mathrm{a}$ & $579 a$ & $1196 b$ & $1194 a$ & $168 b$ & $450 \mathrm{a}$ \\
\hline
\end{tabular}

Table 3. Leaf and root $\mathrm{Na}^{+} / \mathrm{K}^{+}$ratios, membrane damage (MD), osmotic potential $\left(\Psi_{\mathrm{s}}\right)$ and relative water content (RWC) in leaves of two cashew rootstocks exposed to different $\mathrm{NaCl}$ levels for two weeks. Statistics as in Table 1.

\begin{tabular}{|c|c|c|c|c|c|c|}
\hline Genotypes & $\begin{array}{l}\mathrm{NaCl} \\
(\mathrm{mM})\end{array}$ & $\begin{array}{l}\mathrm{Na}^{+} / \mathrm{K}^{+} \\
\text {(Root) }\end{array}$ & $\begin{array}{l}\mathrm{Na}^{+} / \mathrm{K}^{+} \\
\text {(Leaf) }\end{array}$ & $\begin{array}{l}\text { MD } \\
(\%)\end{array}$ & $\begin{array}{c}\Psi_{\mathrm{s}} \\
(-\mathrm{MPa})\end{array}$ & $\begin{array}{r}\text { RWC } \\
(\%)\end{array}$ \\
\hline \multirow[t]{5}{*}{$\overline{\mathrm{CCP}} 06$} & 0 & 0.91 & 0.26 & $21 \mathrm{c}$ & $1.16 \mathrm{a}$ & $92 a$ \\
\hline & 50 & 3.10 & 1.15 & $26 b$ & $1.42 \mathrm{c}$ & $92 \mathrm{a}$ \\
\hline & 100 & 5.70 & 1.19 & $30 \mathrm{a}$ & $1.47 \mathrm{c}$ & $90 a$ \\
\hline & 150 & 5.81 & 1.37 & $32 \mathrm{a}$ & $1.49 \mathrm{c}$ & 89ab \\
\hline & 200 & 8.27 & 1.22 & $31 \mathrm{a}$ & $1.51 \mathrm{c}$ & $90 \mathrm{a}$ \\
\hline \multirow[t]{5}{*}{$\overline{\mathrm{CCP}} 09$} & 0 & 0.74 & 0.30 & $22 c$ & $1.09 \mathrm{a}$ & $94 a$ \\
\hline & 50 & 3.16 & 1.08 & $23 c$ & $1.30 \mathrm{bc}$ & $91 \mathrm{a}$ \\
\hline & 100 & 4.48 & 1.23 & $26 b$ & $1.36 \mathrm{bc}$ & $90 a$ \\
\hline & 150 & 6.34 & 1.41 & $28 b$ & $1.28 \mathrm{~b}$ & $87 b c$ \\
\hline & 200 & 6.62 & 1.28 & $27 b$ & $1.27 \mathrm{~b}$ & $85 c$ \\
\hline
\end{tabular}

cashew rootstocks (Figure 1A). The free amino acid concentration was significantly increased in leaves of the salt-treated tolerant genotype, yet it was not significantly affected in the sensitive genotype (Figure 1B). In addition, the free amino acid concentration in roots was increased by 3 -fold at $200 \mathrm{mM} \mathrm{NaCl}$ in both genotypes (Figure 1B). Proline accumulation in both roots and leaves of the CCP 06 and CCP 09 plants was significantly induced by salt, but the calculated proline concentration on tissue water basis was quantitatively very low, achieving no more than $1 \mathrm{mM}$ (Figure 1C). The salt treatment induced the accumulation of soluble sugars in leaves of the tolerant rootstock, but it decreased the leaf soluble sugars in the sensitive one (Figure 1D). Moreover, the root soluble sugar concentration was significantly reduced only in the sensitive rootstock by the salt treatment.

\section{DISCUSSION}

In the current study, the differential salt tolerance of the cashew genotypes (CCP 06 and CCP 09) was evaluated in terms of several physiological variables. Our data confirm previous results (Ferreira-Silva, 2004), evidencing that the CCP 09 genotype exhibited better growth under $\mathrm{NaCl}$ salinity. Munns (2002) and Flowers (2004) reported that salt-tolerant plants show greater ability to survive and maintain continued growth under salinity, especially perennial species. In other important crops such as Citrus sp. (Storey and Walker, 1999), tomato (Cuartero and Fernández-Muñoz, 1999; Estañ et al., 2005), and Rosa sp. (Wahome et al., 2001) differences in growth have been used as indicators of salt tolerance. Besides, the differential growth response of the tested cashew rootstocks to $\mathrm{NaCl}$ salinity was accompanied by distinct visual symptoms of leaf injury. 

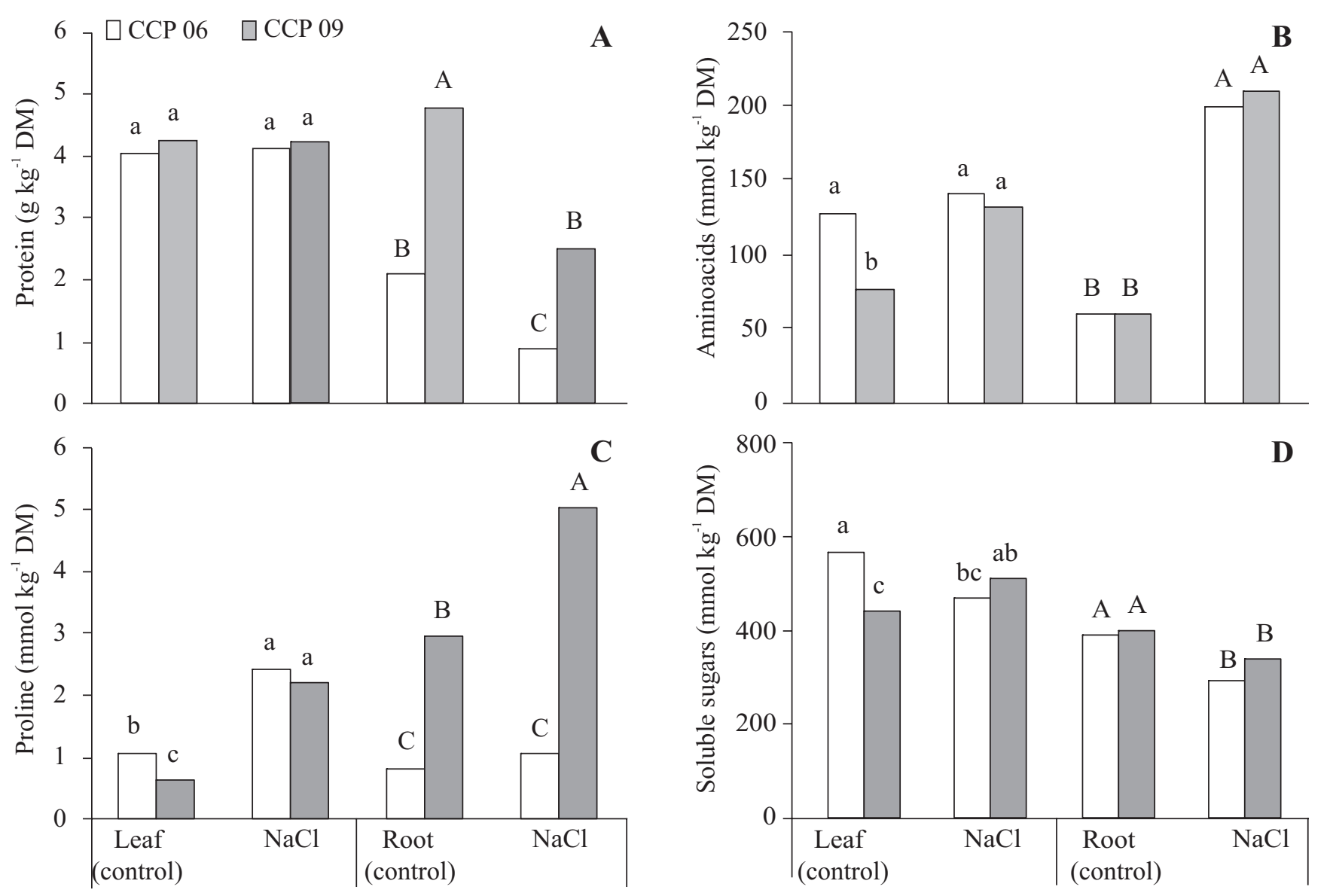

Figure 1. Concentrations of soluble proteins (A), free amino acids (B), proline $(\mathbf{C})$ and total soluble sugars (D) in leaves and roots of cashew plants exposed to the absence (control) or $200 \mathrm{mM} \mathrm{NaCl}$ for two weeks. Significant differences among means in leaves are indicated by lower case letters and, in roots, by upper case letters at $P \leq 0.05(n=4)$.

As the two cashew genotypes did not show significant differences in the $\mathrm{Na}^{+}, \mathrm{Cl}^{-}$, and $\mathrm{K}^{+}$ concentrations, it is suggested that the visual symptoms of leaf injury were not associated with ionic toxicity but rather they were probably triggered by indirect salt effects. Plants exposed to salinity for a short term generally suffer salt-induced osmotic stress (Munns, 2002). Moreover, salt stress induces several secondary effects such as oxidative stress, senescence, programmed cell death, etc. that might alter the plant phenotype (Munns and Tester, 2008). Several investigators have directly associated salt sensitivity with saline ion concentration in plant tissues, especially in leaves (e.g., Storey and Walker, 1999; Wahome et al., 2001; García-Sánchez et al., 2002). However, a direct relationship between toxic ion accumulation in plant tissues and salt tolerance has not been confirmed in other reports presumably because ion partitioning at the cellular level, especially in cytosol and vacuole, is not yet known (Munns, 2002).

The $\mathrm{K}^{+}$partitioning pattern between leaves and roots was very similar for the two tested genotypes in all treatments (Table 2 ). However, root $\mathrm{K}^{+}$concentration was drastically reduced in salt-treated plants in agreement with a previous study (Viégas et al., 2001). High external $\mathrm{Na}^{+}$concentrations could reduce $\mathrm{K}^{+}$uptake due to competition on the binding sites of membrane transporters reducing the $\mathrm{K}^{+}-\mathrm{Na}^{+}$selectivity (Amtman and Maathuis, 1999). Also, membrane stability could be affected by $\mathrm{Na}^{+}$-induced $\mathrm{Ca}^{2+}$ displacement on the root cell surface, allowing $\mathrm{K}^{+}$leakage (Cramer et al., 1985). In addition, it is likely that the increment in the leaf $\mathrm{K}^{+}$ concentration was more associated with a 'concentration effect' attributed to a salt-induced growth restriction than 
to increased $\mathrm{K}^{+}$retrieval from the roots to the leaves.

It is estimated that $\mathrm{K}^{+}$concentration in the cytosol of plant cells ranges from 100 to $150 \mathrm{mM}$ and $\mathrm{Na}^{+}$ concentrations above $100 \mathrm{mM}$ are sufficient to inhibit several $\mathrm{K}^{+}$-dependent cytosolic enzymes (Amtman and Maathuis, 1999). $\mathrm{A} \mathrm{Na}^{+} / \mathrm{K}^{+}$ratio near to 1 could indicate the threshold value among the minimal $\mathrm{K}^{+}$concentration needed to maintain the $\mathrm{K}^{+}$-dependent metabolic functions and the maximal tolerable $\mathrm{Na}^{+}$concentration. In this context, the increase observed in the root $\mathrm{Na}^{+} / \mathrm{K}^{+}$ ratios in the salt-treated plants of both genotypes was a consequence of simultaneous $\mathrm{Na}^{+}$accumulation and $\mathrm{K}^{+}$ decrease. These changes could explain, at least in part, the root growth impairment due to $\mathrm{Na}^{+}$toxicity and $\mathrm{K}^{+}$ nutritional imbalance (Viégas et al., 2001).

In this study, concentrations above $50 \mathrm{mM} \mathrm{NaCl}$ reduced dramatically $E$ and stomatal opening in both genotypes (Table 1). In cashew leaves $E$ has been closely related to the $\mathrm{CO}_{2}$ assimilation (Souza et al., 2005), which is a limiting process to plant growth under salinity (García-Sánchez et al., 2002; Moya et al., 2003). However, the two tested genotypes displayed similar responses in transpiration rates, suggesting that other processes such as reserve mobilization from the remaining cotyledons and dark respiration could contribute to the differential dry mass accumulation between them. In fact, the net dry mass yield under salt conditions is complex and it is enabled by several physiological processes in addition to $\mathrm{CO}_{2}$ assimilation rate (García-Sánchez and Syvertsen, 2006; López-Climent et al., 2008).

The tolerant genotype showed lower leaf MD, as indicated by $\mathrm{K}^{+}$leakage, than the sensitive one, especially at high $\mathrm{NaCl}$ levels. Based on Mansour and Salama (2004) membrane lipid changes might explain the salt sensitivity of CCP 06 . Interestingly, when the tolerant genotype was exposed to high $\mathrm{NaCl}$ salinity, it exhibited lower degree of leaf hydration, as indicated by RWC, and less negative leaf $\Psi_{\text {s }}$ compared with the sensitive one. Thus, these variables were not related to the differences in salt tolerance between the genotypes we evaluated.

Organic solute accumulation in the leaves of salttreated plants may suggest the contribution of these compounds in cell structure protection and as sources of metabolites for the growing tissues in the tolerant genotype (Munns et al., 2006). This salt-induced response could be associated with the improved growth observed in CCP 09. In addition, the maintenance of soluble sugar level in roots of the tolerant genotype could be associated with decreasing growth under salinity. Sugar shortage constraints root growth under stress conditions, as it impairs essential processes such as ion uptake and synthesis of biomolecules (Silveira et al., 2003a).

Salt stress caused more significant changes in protein and amino acid metabolism in roots than in leaves (Figs. 1A, 1B and 1C). Such metabolic changes under high salinity were strictly associated with the decreased root growth in both genotypes (Table 1). This finding is in disagreement with what has been generally reported, with the notion that leaves instead of roots are more sensitive to salt stress in the majority of crops (Munns, 2005). However, our data suggest that roots were more sensitive to salt stress, reinforcing that the selection of tolerant rootstocks could be a good strategy to allow salt tolerance in grafting plants (Zijlstra et al., 1994).

In spite of the salt-induced increase in the proline concentration in leaves and roots of both genotypes, it seems that the accumulation of this organic solute was not quantitatively sufficient to play a significant role in osmotic adjustment, but it could be involved in cell structure protection (Viégas and Silveira, 1999), as a high concentration of proline is not required for plasma membrane protection. These results corroborate the hypothesis that free amino acid and proline accumulation in cashew tissues is mainly a consequence of saltinduced disturbances in protein and amino acid metabolism rather than an adaptative mechanism of protection (Viégas and Silveira, 1999; Viégas et al., 1999; Silveira et al., 2003b).

In summary, the physiological indicators studied here were not able to clearly explain the differences in salt tolerance between the cashew genotypes. However, leaf MD and compatible organic solute accumulation were associated with differential responses of the two cashew genotypes under $\mathrm{NaCl}$ salinity.

Acknowledgements: The authors acknowledge the Conselho Nacional de Desenvolvimento Científico e Tecnológico (CNPq) and Fundação Cearense de Apoio ao Desenvolvimento Científico e Tecnológico (FUNCAP) for financial support. J.A.G.S. is a CNPq research scientist and S.L.F.S. and E.L.V. hold CNPq fellowships. Thanks are due to Dr. João Rodrigues de Paiva (EMBRAPA/CNPAT) for his helpful suggestions and for providing the cashew nuts. 


\section{REFERENCES}

Amtmann A, Maathuis FJM (1999) $\mathrm{K}^{+}$nutrition and $\mathrm{Na}^{+}$ toxicity: The basis of cellular $\mathrm{K}^{+} / \mathrm{Na}^{+}$ratios. Ann. Bot. 84:123-133.

Ashraf M, Ahmad S (2000) Influence of sodium on ion accumulation, yield components and fibre characteristics in salt-tolerant and salt-sensitive lines of cotton (Gossypium hirsutum L.). Field Crops Res. 66:115-127.

Ashraf M, Harris PJC (2004) Potential biochemical indicators of salinity resistance in plants. Plant Sci. 66:3-18.

Bates LS, Waldren RP, Teare ID (1973) Rapid determination of free proline for water stress studies. Plant Soil 9:205-207.

Blumwald E, Aharon GS, Apse MP (2000) Sodium transport in plant cells. Biochim. Biophys. Acta 1465:140-151.

Bradford MM (1976) A rapid and sensitive method for the quantitation of microgram quantities of protein utilizing the principle of protein-dye binding. Anal. Biochem. 72:248-254.

Cavalcanti FR, Oliveira JTA, Martins-Miranda AS, Viégas RA, Silveira JAG (2004) Superoxide dismutase, catalase and peroxidase activities do not confer protection against oxidative damage in salt-stressed cowpea leaves. New Phytol. 163:563-571.

Cramer GR, Lauchli A, Politic VS (1985) Displacement of calcium by sodium from the plasmalemma of root cells: primary response to salt stress. Plant Physiol. 79:207-211.

Cuartero J, Fernández-Muñoz R (1999) Tomato and salinity. Sci. Hort. 78:83-125.

Dubois M, Gilles KA, Hamilton JK, Roberts PA. Smith F (1956) Colorimetric method for determination of sugar and related substances. Anal. Chem. 28:350-356.

Estañ MT, Martinez-Rodriguez MM, Perez-Alfocea F, Flowers TJ, Bolarin MC (2005) Grafting raises the salt tolerance of tomato through limiting the transport of sodium and chloride to the shoot. J. Exp. Bot. 56:703-712.

Ferreira-Silva SL (2004) Transpiration and $\mathrm{Na}^{+}$and $\mathrm{Cl}^{-}$ partitioning in grafted seedlings and rootstocks of different cashew genotypes exposed to salt stress. Fortaleza, Universidade Federal do Ceará, M.Sc. thesis.

Flowers TJ (2004) Improving crop salt tolerance. J. Exp. Bot. 55:307-319.
García-Sánchez F, Syvertsen JP (2006) Salinity tolerance of cleopatra mandarin and carrizo citrange citrus rootstock seedlings is affected by $\mathrm{CO}_{2}$ enrichment during growth. J. Am. Soc. Hort. Sci. 131:24-31.

García-Sánchez F, Jifon JL, Carvajal M, Syvertsen JP (2002) Gas exchange, chlorophyll and nutrient contents in relation to $\mathrm{Na}^{+}$and $\mathrm{Cl}^{-}$accumulation in Sunburst mandarin grafted on different rootstocks. Plant Sci. 162:705-712.

Grattan SR, Grieve CM (1999) Salinity-mineral nutrient relations in horticultural crops. Sci. Hort. 78:127-157.

Hoagland DR, Arnon DI (1950) The water-culture method for growing plants without soil. California Agricultural Experiment Station, Berkeley, 32p. (Circular 347).

López-Climent MF, Arbona V, Pérez-Clemente RM, Gómez-Cadenas A (2008) Relationship between salt tolerance and photosynthetic machinery performance in citrus. Environ. Exp. Bot. 62:176-184.

Matos NN, Teixeira Junior AC, Silveira JAG (2003) Influence of rootstock on physiological behavior of grafted cashew nut tree (Anacardium occidentale L.) under two stress conditions. Braz. J. Frut. 25:27-31.

Mansour MMF, Salama KHA (2004) Cellular basis of salinity tolerance in plants. Environ. Exp. Bot. 52:113-122.

Moya JL, Gómez-Cadenas A, Primo-Millo E, Talon M (2003) Chloride absorption in salt-sensitive Carrizo citrange and salt-tolerant Cleopatra mandarin citrus rootstocks is linked to water use. J. Exp. Bot. 54:825-833.

Munns R (2002) Comparative physiology of salt and water stress. Plant Cell Environ. 25:659-151.

Munns R (2005) Genes and salt tolerance: bringing them together. New Phytol. 167:645-663.

Munns R, Tester M (2008) Mechanisms of salinity tolerance. Annu. Rev. Plant Biol. 59:651-81.

Munns R, James RA, Laüchli A (2006) Approaches to increasing the salt tolerance of wheat and other cereals. J. Exp. Bot. 57:1025-1043.

Santa-Cruz A, Martinez-Rodriguez MM, Perez-Alfocea F, Romero-Aranda R, Bolarin MC (2002) The rootstock effect on the tomato salinity response depends on the shoot genotype. Plant Sci. 162:825-831.

Silveira JAG, Costa RCL, Viégas RA, Oliveira JTA, Figueiredo MVB (2003a) N-compound accumulation and carbohydrate shortage on $\mathrm{N}_{2}$ fixation in droughtstressed and rewatered cowpea plants. Spanish J. Agric. Res. 1: 65-75. 
Silveira JAG, Viégas RA, Rocha IMA, Moreira ACOM, Moreira RA, Oliveira JTA (2003b) Proline accumulation and glutamine synthetase activity are increased by salt-induced proteolysis in cashew leaves. J. Plant Physiol. 160:115-123.

Souza RP, Ribeiro RV, Machado EC, Oliveira RF, Silveira JAG (2005) Photosynthetic responses of young cashew plants to varying environmental conditions. Pesq. Agropec. Bras. 40:735-744.

Storey R, Walker RR (1999) Citrus and salinity. Sci. Hort. 78:39-81.

Viégas RA, Melo ARB, Silveira JG (1999) Nitrate reductase activity and proline accumulation in cashew (Anacardium occidentale L.) in response to salt $(\mathrm{NaCl})$ shock. Braz. J. Plant Physiol. 11:21-28.

Viégas RA, Silveira JAG (1999) Ammonia assimilation and proline accumulation in young cashew plants during long-term exposure to $\mathrm{NaCl}$-salinity. Braz. J. Plant Physiol. 11:153-159.

Viégas RA, Silveira JAG, Junior ARL (2001) Effects of $\mathrm{NaCl}$-salinity on growth and inorganic solute accumulation in young cashew plants. Braz. J. Environ. Agric. Eng. 5:216-222.

Wahome PK, Jesch HH, Grittner I (2001) Mechanisms of salt stress tolerance in two rose rootstocks: Rosa chinensis 'Major' and R. rubiginosa. Sci. Hort. 87:207-216.

Yemm HE, Cocking EC (1955) The determination of amino acids with ninhydrin. Analyst 80:209-213.

Zijlstra S, Groot SPC, Jansen J (1994) Genotypic variation of rootstocks for growth and production in cucumber; possibilities for improving the root system by plant breeding. Sci. Hort. 56:185-196. 